\title{
SCIDiC
}

\author{
International Journal of Dentistry and Oral Science (IJDOS) \\ ISSN: 2377-8075
}

\section{Blue Tea Extract Based Preparation Of Mouthwash And Its Cytotoxic Activity}

Research Article

Ananya $\mathrm{R}^{1}$, Arvina Rajasekar ${ }^{2}$, S Rajeshkumar ${ }^{3}$

${ }^{1}$ Saveetha Dental College and Hospitals, Saveetha Institute of Medical and Technical Sciences (SIMATS), Saveetha University, Chennai- 77, India.

${ }^{2}$ Senior Lecturer, Department of Periodontics, Saveetha Dental College and Hospitals, Saveetha Institute of Medical and Technical Sciences [SIMATS], Saveetha University, Chennai- 77, India.

${ }^{3}$ Associate Professor, Department of Pharmacology, Saveetha Dental College and Hospitals, Saveetha Institute of Medical and Technical Sciences [SIMATS], Saveetha University, Chennai- 77, India.

\section{Abstract}

Background: Blue tea is a caffeine-free herbal infusion produced by dried or fresh Clitoria ternatea plant leaves. The blue tea is high in antioxidants, which shield the body from free radical damage.

Aim: The aim of this study was to prepare mouthwash using blue tea and to assess its cytotoxic activity.

Materials and Methods: $5 \mathrm{gms}$ of the dried leaves of Clitoria ternatea plant was taken in $100 \mathrm{ml}$ of water and then boiled. It is later cooled down, filtered and thus forming the extract. For the mouthwash, 0.3 grams of sucrose, 0.001 grams of preservative and 0.01 gms of sodium lauryl sulphate (SLS) was added to $1 \mathrm{ml}$ of concentrated extract and then $10 \mathrm{ml}$ of distilled water was added. Brine shrimp lethality assay technique was used to assess the cytotoxic effect.

Results: Unpaired t test showed that the number of brine shrimps alive after 24 hours in Clitoria ternatea mouthwash was significantly lesser when compared to the control at various concentrations even though the magnitude of difference was lesser at higher concentrations ( $p>0.05$ ). Also, the comparison of the mean brine shrimp count alive after 24 hours between different concentrations and the control was calculated using a one way ANOVA test. There was a significant decrease in the number of brine shrimps from lower concentration to higher concentration ( $\mathrm{p}>0.05)$.

Conclusion: The present study reveals that the prepared blue tea extract based mouthwash exhibited cytotoxic activity at various concentrations even though the magnitude of difference was lesser at higher concentrations.

Keywords: Blue Tea; Herbal Mouthwash; Green Synthesis; Cytotoxicity; Innovative Technique.

\section{Introduction}

Herbal teas are becoming more popular as more people become aware of the possible negative effects of caffeinated beverages such as daily tea and coffee[1-9]. Herbal teas made from flowers such as chamomile and blue pea have become popular among tea drinkers all over the world. Though chamomile tea is well-known for its mild, calming flavour and ability to relieve tension, blue pea flower tea is less well-known[10-11].

Blue tea, also known as butterfly pea flower tea, is a caffeine-free herbal infusion produced by infusing dried or fresh Clitoria ternatea plant leaves [12-14]. The best part about blue tea is that it contains no caffeine and is loaded with antioxidants. The butterfly- pea, also known as blue pea or pigeon wings, is a plant that can be found in Southeast Asia [15]. Catechins, found in blue tea, are said to help burn belly fat and aid weight loss. Drinking butterfly-pea flowers soaked in warm water is said to boost metabolism, causing the body to consume more calories [16].

The blue tea is high in antioxidants, making it an excellent addition to your detox diet. Antioxidants shield the body from free radical damage. Butterfly-pea flower tea is said to have a calming effect due to its earthy flavour $[16,17]$. The tea is said to have stress-relieving properties and may also assist in the reduction of anxiety symptoms [18]. As a natural diuretic, blue tea is said to assist in the loss of water weight. While there isn't much clinical evidence to indicate that blue tea can help with diabetes manage-

*Corresponding Author:

Dr. Arvina Rajasekar

Senior Lecturer, Department of Periodontics, Saveetha Dental College and Hospitals, Saveetha Institute of Medical and Technical Sciences [SIMATS], Saveetha University, Chennai- 77 , India.

Tel: +919486442309

E-mail: arvinar.sdc@saveetha.com

Received: September 13, 2021

Accepted: September 22, 2021

Published: September 23, 2021

Citation: Ananya R, Arvina Rajasekar, S Rajeshkumar. Blue Tea Extract Based Preparation Of Mouthwash And Its Cytotoxic Activity. Int J Dentistry Oral Sci. 2021;8(9):4620-4623. doi: http://dx.doi.org/10.19070/2377-8075-21000941

Copyright: Dr. Arvina Rajasekar ${ }^{\circ} 2021$. This is an open-access article distributed under the terms of the Creative Commons Attribution License, which permits unrestricted use, distribution and reproduction in any medium, provided the original author and source are credited. 
ment, it is said to help regulate blood sugar levels [19].

There is a lot of debate and discussion about the advantages of blue tea over green tea. On the same topic, research is ongoing, and it has been scientifically proven that blue tea contains more antioxidants than green tea [18-21]. Our team has extensive knowledge and research experience that has translated into high quality publications [22-41]. Therefore the aim of this study was to prepare mouthwash using blue tea and assess its cytotoxic activity.

\section{Materials and Methods}

\section{Preparation of Blue tea extract}

5 gms of the dried leaves of Clitoria ternatea plant was taken in 100 $\mathrm{ml}$ of water and then boiled. It is later cooled down, filtered and thus forming the extract. (Figure 1).

\section{Preparation of mouthwash}

For making the mouthwash, 0.3 grams of sucrose was added as the sweetening agent, 0.001 grams of preservative was added and 0.01 gms of sodium lauryl sulphate (SLS) as the foaming agent, to this $1 \mathrm{ml}$ of concentrated extract and $10 \mathrm{ml}$ of distilled water was added (Figure 2).

\section{Brine shrimp lethality assay}

Brine shrimp eggs were purchased commercially. Brine shrimp eggs were incubated for 48 hours in a small water tank containing brine/seawater for hatching. The larvae were utilised for the experiment after 24 hours (nauplii). 10-12 mL of salt water was used to fill 6 well ELISA plates. To that end, 10 nauplii were slowly added to each well containing varying concentrations of mouthwash (control, $5 \mu \mathrm{l}, 10 \mu \mathrm{l}, 20 \mu \mathrm{l}, 40 \mu \mathrm{l}$, and $80 \mu \mathrm{l}$ ). After 24 hours, the plates were incubated. To achieve triplicate values, this technique was performed three times. After 24 hours, the ELISA plates were examined for the presence of live nauplii and the number of dead nauplii was determined using the formula (number of dead nauplii / number of live nauplii x 100) [42, 43]. (Figure 3).

\section{Results}

In the present study, brine shrimp lethality assay was done to assess the cytotoxic effect of various concentrations of blue tea extract based mouthwash. Unpaired t test was done to compare the number of brine shrimps alive after 24 hours between Clitoria ternatea mouthwash and the control. The number of brine shrimps alive after 24 hours in Clitoria ternatea mouthwash was significantly lesser when compared to the control at various concentrations even though the magnitude of difference was lesser at higher concentrations ( $\mathrm{p}>0.05)$. (Figure 4).

Also, the comparison of the mean brine shrimp count alive after 24 hours between different concentrations and the control was calculated using a one way ANOVA test. Maximum mortality was noted in the concentration $80 \mu$ l. There was a significant decrease in the number of brine shrimps from lower concentration to higher concentration ( $\mathrm{p}>0.05)$. (Figure 5).

\section{Discussion}

The present study was done to evaluate the cytotoxic activity of the blue tea extract using Clitoria ternatea.

The results of the current study showed that maximum mortality was noted in the concentration $80 \mu l$. There was a significant decrease in the number of brine shrimps from lower concentration to higher concentration.

A study on Clitoria ternatea extract suggested that the extract has substantial cytotoxic effect on cells and also has antioxidant effect [44]. Our study results are in accordance with the previous studies. The presence of the cytotoxic compound in cells can result in a variety of cell fates. Necrosis occurs when cells lose their membrane integrity and results in cell death [45]. The cells may stop actively growing and dividing or they may trigger a genetic programme that causes regulated cell death [46]. Pharmaceutical companies also use cytotoxicity assays to assess cytotoxicity [46, 47]. Researchers can either look for cytotoxic compounds that aim to quickly separate cancer cells or they can test preliminary drugs for cytotoxic effects before investing in their pharmaceutical production [1]. In this research, one of the most important approaches to assessing cell viability and cytotoxic effects was assessing the lethality of brine shrimp nauplii.

However, the current study had certain drawbacks such as the use of brine shrimp lethality assay to assess the cytotoxic effect. Since there is a lack of toxicity studies and clinical trials addressing the cytotoxicity of Clitoria ternatea, further research is needed to fully understand the cytotoxic impact of Clitoria ternatea. However, this research has aided in proving the bioactive potential of inexpensive natural plant extracts. More in vitro and in vivo research is needed to better understand the uses of this extract in the treatment of various illnesses as a traditional medicine that can substitute antibiotic overuse, improve patient compliance and minimise systemic toxicity or other adverse effects.

Figure 1. Preparation of Blue tea extract.

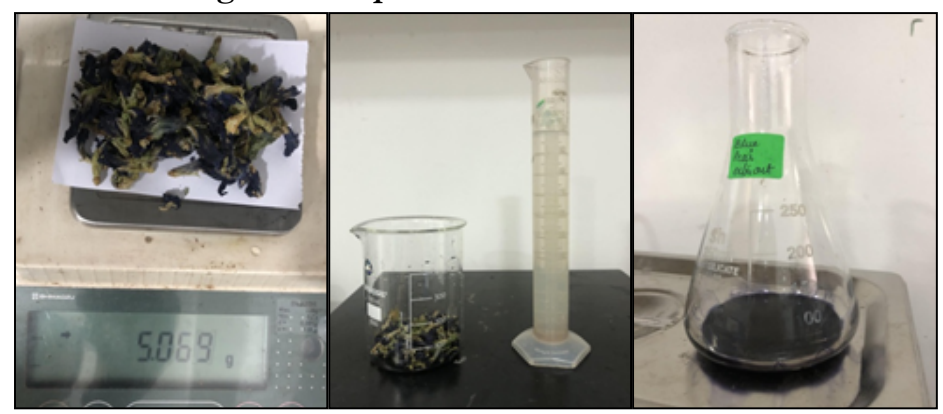


Figure 2. Preparation of Blue tea mouthwash.

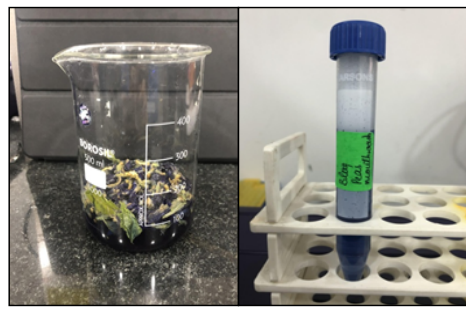

Figure 3. Isolation of brine shrimp eggs and incorporation of Blue tea mouthwash.

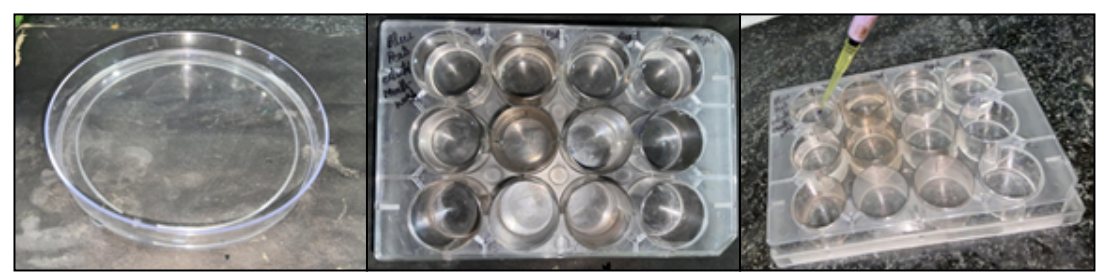

Figure 4. Bar graph shows the cytotoxic activity of Clitoria ternatea mouthwash and control against brine shrimp at various concentrations. The $\mathbf{X}$ axis represents the various concentrations of control and Clitoria ternatea extract in units of $\mu 1$ and the $\mathrm{Y}$ axis represents the number of brine shrimps. Blue represents the control and green represents the Clitoria ternatea extract. The graph shows that the number of brine shrimps alive in Clitoria ternatea mouthwash was significantly lesser when compared to the control at various concentrations even though the magnitude of difference was lesser at higher concentrations $(\mathrm{p}>0.05)$ (unpaired t test).

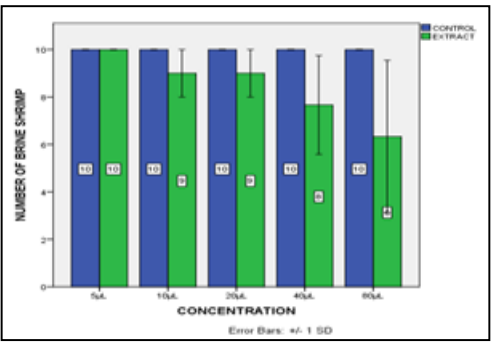

Figure 5. Bar graph shows the cytotoxic activity of Clitoria ternatea mouthwash against brine shrimp at various concentrations. The $\mathbf{X}$ axis represents the various concentrations of Clitoria ternatea extract in units of $\mu 1$ and the $\mathrm{Y}$ axis represents the number of brine shrimps. There was a significant decrease in the number of brine shrimps from lower concentration to higher concentrations. ( $p>0.05)$ (One Way ANOVA).

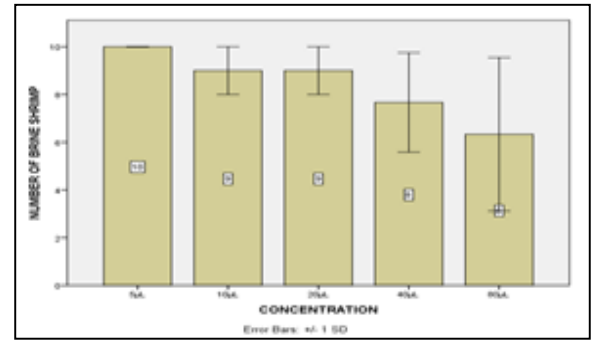

\section{Conclusion}

The present study reveals that the prepared blue tea extract based mouthwash exhibited cytotoxic activity at various concentrations even though the magnitude of difference was lesser at higher concentrations.

\section{Acknowledgement}

The authors would like to acknowledge the help and support rendered by the Department of Periodontics, Department of Nano Biomedicine, Saveetha Dental College and Hospitals, Saveetha Institute of Medical and Technical Sciences, Saveetha University for the constant assistance with the research.

\section{Funding}

The present study is funded by

- Saveetha Institute of Medical and Technical Sciences

- Saveetha Dental College and Hospitals

- Saveetha University

- $\quad$ Sri Kamala Super Market, Chennai.

\section{References}

[1]. Hannemann S, Madrid R, Stastna J, Kitzing T, Gasteier J, Schönichen A, et al. The Diaphanous-related Formin FHOD1 associates with ROCK1 and promotes Src-dependent plasma membrane blebbing. J Biol Chem. 2008 Oct 10;283(41):27891-27903.Pubmed PMID: 18694941

[2]. Albert H, Salt-Works Press. Blue Tea. 1973:22 .

[3]. SAGANA M, RAJASEKAR A, RAJESHKUMAR S. ANTIFUNGAL 
ACTIVITY OF GRAPE SEED EXTRACT MEDIATED ZINC OXIDE NANOPARTICLES-AN In vitro STUDY. Plant Cell Biotechnol Mol Biol. 2020 Aug 25:14-20.

[4]. YUVASHREE C, RAJASEKAR A, RAJESHKUMAR S. CYTOTOXIC EFFECT OF TITANIUM DIOXIDE NANOPARTICLES SYNTHESIZED USING GRAPE SEED EXTRACT: AN in vitro STUDY. Plant Cell Biotechnol Mol Biol. 2020 Aug 26; 21(31-32):120-6.

[5]. SHIVANI N, RAJASEKAR A, RAJESHKUMAR S. ANTIFUNGAL ACTIVITY OF GRAPE SEED EXTRACT MEDIATED TITANIUM OXIDE NANOPARTICLES AGAINST Candida albicans: AN In vitro STUDY. Plant Cell Biotechnol Mol Biol. 2020 Aug 26; 21(35-36):8-15.

[6]. DEVI BV, RAJASEKAR A, RAJESHKUMAR S. ANTIINFLAMMATORY ACTIVITY OF ZINC OXIDE NANOPARTICLES SYNTHESISED USING GRAPE SEED EXTRACT: AN in vitro STUDY. Plant Cell Biotechnol Mol Biol. 2020 Aug 26;21(33-34):6-16

[7]. PEREIRA WD, RAJASEKAR A, RAJESHKUMAR S. GREEN SYNTHESIS OF SELENIUM NANOPARTICLES (SeNPs) USING AQUEOUS EXTRACT OF CLOVE AND CINNAMON. Plant Cell Biotechnol Mol Biol. 2020 Aug 25; 21(29-30):85-91.

[8]. PRANATI T, RAJASEKAR A, RAJESHKUMAR S. ANTI INFLAMMATORY AND CYTOTOXIC EFFECT OF CLOVE AND CINNAMON HERBAL FORMULATION. Plant Cell Biotechnol Mol Biol. 2020 Aug 25; 21(29-30):69-77.

[9]. ANJUM AS, RAJASEKAR A, RAJESHKUMAR S. SYNTHESIS AND CHARACTERIZATION OF GRAPE SEED MEDIATED TITANIUM DIOXIDE NANOPARTICLES: AN in vitro STUDY. Plant Cell Biotechnol Mol Biol. 2020 Aug 26; 21(33-34):17-23.

[10]. Walsh JM. Tea, Its History and Mystery. 1892

[11]. Rojas-Sandoval J. Clitoria ternatea (butterfly-pea).

[12]. Burgess A. The Book of Tea. Flammarion; 1992: 256

[13]. Dubrin B. Tea culture: History, traditions, celebrations, recipes \& more: History, traditions, celebrations, recipes \& more. Charlesbridge; 2012 Feb $1: 144$

[14]. Afrianto WF, TAMNGE F, HASANAH LN. A relation between ethnobotany and bioprospecting of edible flower Butterfly Pea (Clitoria ternatea) in Indonesia. Asian J Ethnobiol. 2020 Oct 20;3(2).

[15]. Ramli ME, Salleh RM, Tajarudin HA, Zulkurnain M. Influence of amylose content on phenolics fortification of different rice varieties with butterfly pea (Clitoria ternatea) flower extract through parboiling. LWT. $2021 \mathrm{Jul}$ 1;147:111493

[16]. Minh NP. Efficacy of steaming, vacuum drying and stir-frying to total phenolic, flavonoid and organoleptic properties in butterfly pea flower (Clitoria ternatea) tea. J. Entomol. Res. 2020;44(4):621-4.

[17]. Marpaung AM, Lee M, Kartawiria IS. The Development of Butterfly pea (Clitoria ternatea) Flower Powder Drink by Co-crystallization. IFSTJ. 2020 Jul 31;3(2):34-7.

[18]. Escher GB, Wen M, Zhang L, Rosso ND, Granato D. Phenolic composition by UHPLC-Q-TOF-MS/MS and stability of anthocyanins from Clitoria ternatea L. (butterfly pea) blue petals. Food Chem. 2020 Nov 30;331:127341. Pubmed PMID: 32569972.

[19]. Rajan M, Mudalib SK, Izirwan I. Aqueous Extraction of Blue Dye from Butterfly Pea Flower: An Optimization Study Using Response Surface Methodology. Proceedings of the International Conference on Modern research in Engineering, Technology \& Science.2019.

[20]. Marpaung AM, Chiang S. The Appropriate Way to Serve Butterfly Pea Flower Drink at Home.Proc. ICONIET. 2018;2(2):134-7.

[21]. Kaewmanee K, Priprem A, Preeprame S. Stability and staining property of gel from roselle calyx extract and butterfly pea flower. Planta Med. 2011 Aug;77(12):PK13.

[22]. Ramesh A, Varghese S, Jayakumar ND, Malaiappan S. Comparative estimation of sulfiredoxin levels between chronic periodontitis and healthy patients - A case-control study. J Periodontol. 2018 Oct;89(10):1241-1248.Pubmed PMID: 30044495.

[23]. Paramasivam A, Priyadharsini JV, Raghunandhakumar S, Elumalai P. A novel COVID-19 and its effects on cardiovascular disease. Hypertens Res. $2020 \mathrm{Jul} ; 43(7): 729-30$

[24]. S G, T G, K V, Faleh A A, Sukumaran A, P N S. Development of 3D scaffolds using nanochitosan/silk-fibroin/hyaluronic acid biomaterials for tissue engineering applications. Int J Biol Macromol. 2018 Dec;120(Pt A):876885.Pubmed PMID: 30171951

[25]. Del Fabbro M, Karanxha L, Panda S, Bucchi C, Doraiswamy JN, Sankari $\mathrm{M}$, et al. Autologous platelet concentrates for treating periodontal infrabony defects. Cochrane Database Syst Rev. 2018;11: CD011423.

[26]. Paramasivam A, Vijayashree Priyadharsini J. MitomiRs: new emerging microRNAs in mitochondrial dysfunction and cardiovascular disease. Hypertens Res. 2020 Aug;43(8):851-853.Pubmed PMID: 32152483.

[27]. Jayaseelan VP, Arumugam P. Dissecting the theranostic potential of exosomes in autoimmune disorders. Cell Mol Immunol. 2019 Dec;16(12):935-936. Pubmed PMID: 31619771.

[28]. Vellappally S, Al Kheraif AA, Divakar DD, Basavarajappa S, Anil S, Fouad $\mathrm{H}$. Tooth implant prosthesis using ultra low power and low cost crystalline carbon bio-tooth sensor with hybridized data acquisition algorithm. Comput Commun. 2019 Dec 15;148:176-84.

[29]. Vellappally S, Al Kheraif AA, Anil S, Assery MK, Kumar KA, Divakar DD. Analyzing Relationship between Patient and Doctor in Public Dental Health using Particle Memetic Multivariable Logistic Regression Analysis Approach (MLRA2). J Med Syst. 2018 Aug 29;42(10):183.Pubmed PMID: 30155746.

[30]. Varghese SS, Ramesh A, Veeraiyan DN. Blended Module-Based Teaching in Biostatistics and Research Methodology: A Retrospective Study with Postgraduate Dental Students. J Dent Educ. 2019 Apr;83(4):445-450.Pubmed PMID: 30745352.

[31]. Venkatesan J, Singh SK, Anil S, Kim SK, Shim MS. Preparation, Characterization and Biological Applications of Biosynthesized Silver Nanoparticles with Chitosan-Fucoidan Coating. Molecules. 2018 Jun 12;23(6):1429.Pubmed PMID: 29895803.

[32]. Alsubait SA, Al Ajlan R, Mitwalli H, Aburaisi N, Mahmood A, Muthurangan $\mathrm{M}$, et al. Cytotoxicity of different concentrations of three root canal sealers on human mesenchymal stem cells. Biomolecules. 2018 Sep;8(3):68.

[33]. Venkatesan J, Rekha PD, Anil S, Bhatnagar I, Sudha PN, Dechsakulwatana $\mathrm{C}$, et al. Hydroxyapatite from cuttlefish bone: isolation, characterizations, and applications. Biotechnol Bioprocess Eng. 2018 Aug;23(4):383-93.

[34]. Vellappally S, Al Kheraif AA, Anil S, Wahba AA. IoT medical tooth mounted sensor for monitoring teeth and food level using bacterial optimization along with adaptive deep learning neural network. Measurement. 2019 Mar 1;135:672-7.

[35]. PradeepKumar AR, Shemesh H, Nivedhitha MS, Hashir MMJ, Arockiam $S$, Uma Maheswari TN, et al. Diagnosis of Vertical Root Fractures by Conebeam Computed Tomography in Root-filled Teeth with Confirmation by Direct Visualization: A Systematic Review and Meta-Analysis. J Endod. 2021 Aug:47(8):1198-1214.Pubmed PMID: 33984375.

[36]. R H, Ramani P, Tilakaratne WM, Sukumaran G, Ramasubramanian A, Krishnan RP. Critical appraisal of different triggering pathways for the pathobiology of pemphigus vulgaris-A review. Oral Dis. 2021 Jun 21.Pubmed PMID: 34152662.

[37]. Ezhilarasan D, Lakshmi T, Subha M, Deepak Nallasamy V, Raghunandhakumar S. The ambiguous role of sirtuins in head and neck squamous cell carcinoma. Oral Dis. 2021 Feb 11.Pubmed PMID: 33570800.

[38]. Sarode SC, Gondivkar S, Sarode GS, Gadbail A, Yuwanati M. Hybrid oral potentially malignant disorder: A neglected fact in oral submucous fibrosis. Oral Oncol. 2021 Oct;121:105390.Pubmed PMID: 34147361.

[39]. Kavarthapu A, Gurumoorthy K. Linking chronic periodontitis and oral cancer: A review. Oral Oncol. 2021 Jun 16:105375

[40]. Vellappally S, Al-Kheraif AA, Anil S, Basavarajappa S, Hassanein AS. Maintaining patient oral health by using a xeno-genetic spiking neural network. J Ambient Intell Humaniz Comput. 2018 Dec 14:1-9.

[41]. Aldhuwayhi S, Mallineni SK, Sakhamuri S, Thakare AA, Mallineni S, Sajja R, et al. Covid-19 Knowledge and Perceptions Among Dental Specialists: A Cross-Sectional Online Questionnaire Survey. Risk Manag Healthc Policy. 2021 Jul 7;14:2851-2861.Pubmed PMID: 34262372.

[42]. Biradi M, Hullatti K. Screening of Indian medicinal plants for cytotoxic activity by brine shrimp lethality (BSL) assay and evaluation of their total phenolic content. Drug Dev Ther. 2014;5:139-44.

[43]. Zani CL, Chaves PP, Queiroz R, De Oliveira AB, Cardoso JE, Anjos AM, et al. Brine shrimp lethality assay as a prescreening system for anti-Trypanosoma cruzi activity. Phytomedicine. 1995 Jul;2(1):47-50.Pubmed PMID: 23196100.

[44]. Lakshan SAT, Jayanath NY, Abeysekera WPKM, Abeysekera WKSM. A Commercial Potential Blue Pea (Clitoria ternatea L.) Flower Extract Incorporated Beverage Having Functional Properties. Evid Based Complement Alternat Med. 2019 May 20;2019:2916914.Pubmed PMID: 31236123.

[45]. Fackler OT, Grosse R. Cell motility through plasma membrane blebbing. J Cell Biol. 2008 Jun 16;181(6):879-84.

[46]. Stastna J, Pan X, Wang H, Kollmannsperger A, Kutscheidt S, Lohmann V, et al. Differing and isoform-specific roles for the formin DIAPH3 in plasma membrane blebbing and filopodia formation. Cell Res. 2012 Apr;22(4):72845.Pubmed PMID: 22184005

[47]. Tournaviti S, Hannemann S, Terjung S, Kitzing TM, Stegmayer C, Ritzerfeld J, et al. SH4-domain-induced plasma membrane dynamization promotes bleb-associated cell motility. J Cell Sci. 2007 Nov 1;120(Pt 21):38209. Pubmed PMID: 17959630. 